\title{
PENGARUH PENEMBAKAN LASERPUNKTUR PADA TITIK REPRODUKSI ITIK CAMPBELL (Anas platyrhynchos domesticus) BETINA TERHADAP PRODUKTIVITAS TELUR
}

\section{THE EFFECT OF LASERPUNCTURE SHOOT ON REPRODUCTIVE POINT OF CAMPBELL DUCK (Anas platyrhynchos domesticus) ON THE EGG PRODUCTIVITY}

 \\ R.T. Santanu Adikara ${ }^{4)}$, Benjamin Chr. Tehupuring ${ }^{4)}$, Sri Hidanah ${ }^{5)}$ \\ ${ }^{1)}$ Student, ${ }^{2)}$ Veterinary Reproduction Department, ${ }^{3)}$ Veterinary Public Health Department \\ ${ }^{4)}$ Veterinary Anatomi Department ${ }^{5)}$ Animal Husbandary Department \\ Faculty of Veterinary Medicine, Universitas Airlangga \\ sena.sangga.renata@gmail.com; *Corresponding author: email: twsuprayogi@gmail.com
}

\begin{abstract}
The technology of laserpuncture in livestock is an acupuncture technique using Laser (Light Amplification by Stimulated Emission of Radiation) that is fired at acupuncture points as biological receptors that are related to organs that can provide stimulatory effects. This research was conducted in the laboratory of Airlangga University for 30 days using a sample of 18 cambell ducks divided into 3 treatments and laser shot with 3 days interval. Treatment 0 as control, treatment 1 got laser treatment dose 0,2 joule and treatment 2 got laser treatment dose 0,5 joule. On the final result of the eggs that have been in the production of duck research for 29 days. P2 given laser shootings with a dose of 0.5 joule yielded more eggs with 158 grains compared to P1 given laser shootings with a dose of 0.2 joules yielding 126 grains and $\mathrm{P} 0$ with inactivated laser yielding a total of 86 grains. The conclusion of this study is the shooting of laserpuncture dose of 0.2-0.5 joule can increase egg productivity.

Key words: Laserpuncture, Egg productivity, Reproductive point, Campbell

\section{Pendahuluan}

Pengembangan usaha ternak itik di Indonesia telah menjadi usaha yang memiliki komponen lengkap dari sektor hulu sampai ke hilir. Perkembangan ini dapat memberikan kontribusi nyata dalam pembangunan sub sektor peternakan. Salah satu ternak unggas yang mulai berkembang di masyarakat adalah ternak itik meskipun tidak sepopuler ternak ayam (Atmajaja, 2003). Itik memiliki produktivitas telur yang lebih tinggi dibandingkan dengan ayam kampung dan lebih menguntungkan jika dipelihara secara intensif terkurung sepenuhnya. Semakin terbukanya pasar produk itik ikut mendorong berkembangnya peternakan itik di Indonesia. Pasar telur itik yang selama ini telah terbentuk masih sangat terbuka bagi peningkatan produksi karena permintaan yang ada pun belum bisa terpenuhi semuanya, sedangkan pasar daging itik yang selama ini hanya dipenuhi secara terbatas oleh daging itik Peking yang diimpor, secara perlahan mulai terbuka

lebih luas (Prasetyo dkk, 2010). Salah satunya itik Campbell.

Itik Campbell (Anas platyrhynchos domesticus) disebut juga hasil persilangan antara itik jantan liar dengan itik keturunan hasil kawin silang antara itik Jawa dengan itik Rouen dari Perancis. Itik Campbell memiliki tingkat produksi telur mencapai $27 \%$ lebih tinggi dibandingkan dengan itik Alabio maupun itik Bali yang mencapai 25\% dan 33\% lebih tinggi dari itik Tegal yang mencapai $31 \%$ (Ismoyowati, 2006). Untuk lebih meningkatkan produktivitas telur itik di butuhkan teknologi, salah satunya adalah Akupunktur.

Teknologi laserpunktur pada ternak adalah teknik menggunakan laser (Light Amplification by Stimulated Emission of Radiation) yang ditembakkan pada titik akupunktur sebagai reseptor biologi yang mempunyai hubungan dengan organ terkait yang dapat memberikan efek stimulasi, radiasi dan inhibisi. Stimulasi merupakan pemberian rangsangan agar terjadi peningkatan energi pada titik akupunktur dan
\end{abstract}


dilanjutkan melalui jalur meridian sehingga memberikan efek kapasitasi pada organ target. Laser yang dimaksud adalah laser jenis low laser dengan dosis stimulasi yaitu antara 0,1-0,5 joule (Adikara, 2014). Terbukti pada Penelitian yang dilakukan oleh Rachmawati (2015) menggunakan laser Helium Neon pada itik Madura jantan juga menunjukkan perbedaan yang nyata antara berat badan sebelum dan sesudah perlakuan dengan rerata berat badan akhir 867 gram serta presentase berat karkas yang signifikan pada itik yang diberi penembakan laser Helium Neon.

Laser berkekuatan rendah yang digunakan untuk laserpunktur $(5 \mathrm{~mW}$ sampai $30 \mathrm{~mW}$ ) terbukti dapat meningkatkan aktifitas jaringan seperti peningkatan hormon dan enzim jaringan. Bahkan beberapa penelitian menunjukkan laserpunktur dapat memperbaiki sistem vaskuler (Hardjanto,2001). Penelitian yang dilakukan sebelumnya oleh Guntoro et al., (2002), tentang aplikasi teknologi laserpunktur untuk gertak birahi pada kerbau, hasil penelitiannya membuktikan bahwa teknologi laserpunktur dapat memberikan hasil yang efektif dengan respon birahi yang cepat dan serempak. Penelitian lainnya yang dilakukan oleh Herdis (2010), tentang aplikasi teknologi laserpunktur untuk gertak birahi pada domba Garut, hasil penelitiannya membuktikan bahwa teknologi laserpunktur pada titik-titik reproduksi dapat meningkatkan libido pejantan domba Garut.Pemanfaatan laser pada ternak adalah bertujuan untuk meningkatkan keseimbangan biologis dan kesehatan ternak, selain itu yang terpenting adalah untuk meningkatkan kemampuan produktifitas ternak serta dapat pula meningkatkan kemampuan reproduksi ternak. Sebagai cara untuk mencapai tujuan diatas maka laser ditembakkan pada titik-titik yang berhubungan dengan organ yang berfungsi untuk kesehatan, keseimbangan, produksi, dan reproduksi pada ternak (Adikara, 2001).

Berdasarkan latar belakang tersebut serta mengetahui pentingnya teknologi alternatif laserpunktur untuk meningkatkan aktivitas reproduksi, maka perlu di teliti pengaruh penembakan laserpunktur pada titik reproduksi itik Campbell betina terhadap produktivitas telur.

\begin{abstract}
Analisis Data
Data diolah dan dianalisis menggunakan ANOVA yang dimasukkan kedalam perhitungan statistik SPSS dengan lanjutan Duncan apabila terdapat perbedaan yang nyata $(\mathrm{p} \leq 0,05)$ antar perlakuan.
\end{abstract}

Hasil dan Pembahasan

Tabel 1. Rata-rata \pm Standar Deviasi, Duck Production Itik Campbell Betina Setelah Penembakan Laserpunktur.

\begin{tabular}{|c|c|c|}
\hline PERLAKUAN & $\begin{array}{c}\text { Rata-rata (butir) } \\
\pm \text { Standar } \\
\text { Deviasi }\end{array}$ & $\begin{array}{c}\text { Duck } \\
\text { Production } \\
(\%)\end{array}$ \\
\hline $\mathrm{P}_{\mathrm{O}}$ & $13,667^{\mathrm{a}} \pm 2,73$ & $45,5 \%$ \\
\hline $\mathrm{P}_{1}$ & $21.000^{\mathrm{b}} \pm 2,89$ & $70 \%$ \\
\hline $\mathrm{P}_{2}$ & $26.333^{\mathrm{c}} \pm 3,20$ & $86,6 \%$ \\
\hline a, b dan c : & $\begin{array}{c}\text { Superskrip yang berbeda } \\
\text { perbedaan yang nyata } \\
\text { menunjukkan } \\
(\mathrm{p}<0,05) \text { antar perlakuan. }\end{array}$
\end{tabular}

Berdasarkan hasil ANOVA yang dilanjutkan dengan uji Duncan diketahui bahwa superskrip jumlah telur itik P0 berbeda nyata dengan P1 dan P2, sedangkan P1 juga berbeda nyata dengan P2. P2 yang ditembak laserpunktur dengan dosis $0.5 \mathrm{~J}$ lebih banyak memproduksi telur dibandingkan P1 yang ditembak dengan dosis $0.2 \mathrm{~J}$.

Dari analisis data perbandingan hasil penelitian antara perlakuan yang diberi penembakan laser dan perlakuan yang tidak diberi penembakan laser, menunjukkan hasil yang signifikan. Pada perhitungan akhir P0 menghasilkan telur sejumlah 86 butir, P1 sejumlah 126 butir dan P2 sejumlah 158 butir. Penembakan laser semikonduktor terbukti dapat memberikan efek stimulasi sehingga tercapai peningkatan kapasitas dan efisiensi organ yang digambarkan dalam bentuk peningkatan "Prestasi Biologi" itik (Adikara, 2014).

Aplikasi laserpunktur dengan dosis 0,1-0,5 Joule akan menimbulkan efek stimulasi yaitu peningkatan energi pada titik akupunktur dan memberikan efek kapasitas fisiologis pada organ targetnya. Dosis diatas 0,5 Joule akan menimbulkan efek sedasi yaitu penurunan energi atau penenangan pada kinerja organ yang 


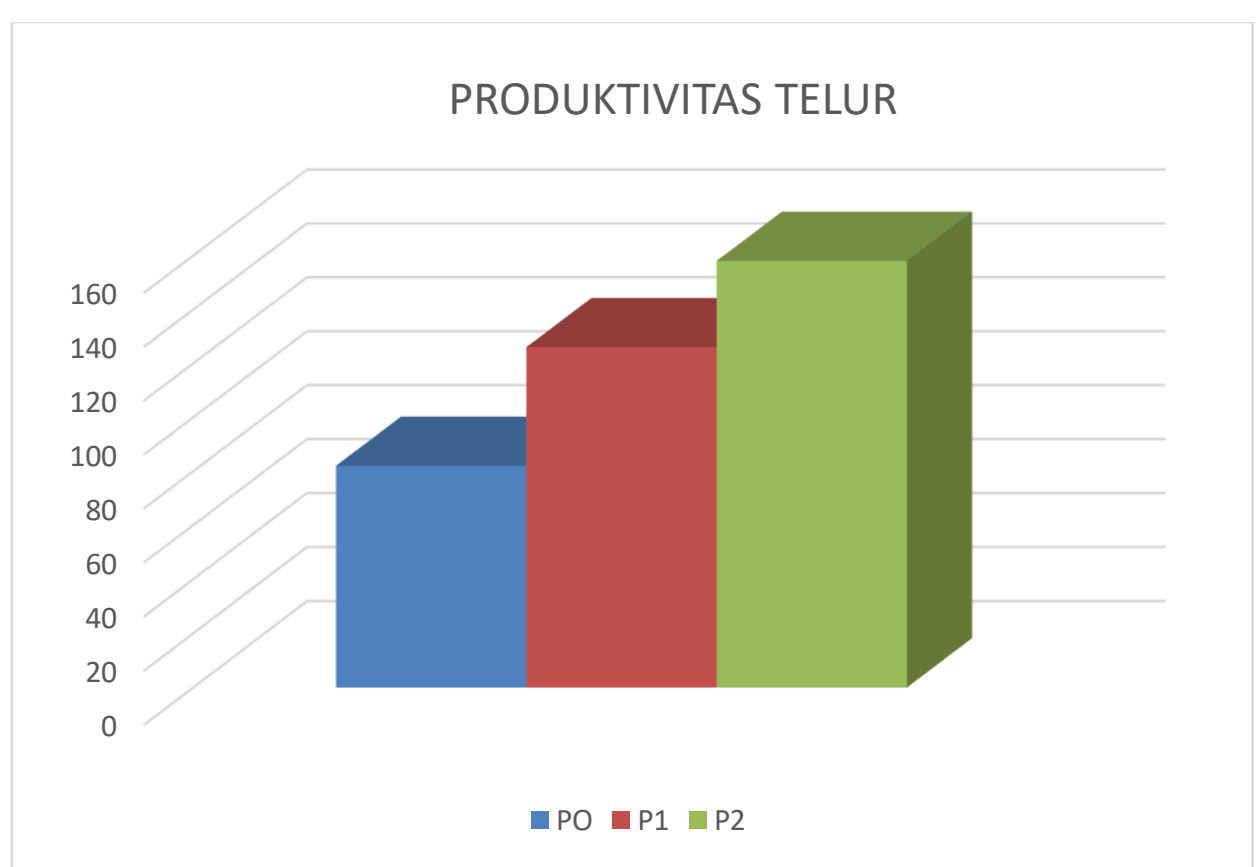

Gambar 1. Produktivitas Telur (butir) Setelah Penembakan Laserpunktur pada Titik Reproduksi Selama 29 Hari dengan Interval Waktu 3 Hari. P0 : tanpa perlakuan; $\mathrm{P} 1$ : dosis $0.2 \mathrm{~J} ; \mathrm{P} 2$ : dosis $0.5 \mathrm{~J}$.

berlebihan sehingga terjadi perimbangan energi yang sesuai dengan kondisi organ (Adikara, 2001). Stimulasi laserpunktur dapat meningkatkan produktivitas telur, produktivitas itik petelur diukur dengan menghitung jumlah telur yang dihasilkan kelompok itik setiap harinya (duckday) dan dijumlahkan setiap bulannya (duck production). Terbukti nyata pada hasil akhir penjumlahan telur yang telah di produksi itik penelitian selama 29 hari. P2 yang diberi penembakan laser dengan dosis 0,5 joule lebih banyak menghasilkan telur yaitu dengan jumlah 158 butir dibandingkan dengan P1 yang di beri penembakan laser dengan dosis 0,2 joule menghasilkan 126 butir dan P0 dengan laser yang di nonaktifkan menghasilkan sejumlah 86 butir.

Penembakan dengan 0,5 joule lebih optimal karena dosis yang lebih besar memberikan stimulasi dan energi yang lebih tinggi sehingga menyeimbangkan sistem reproduksi. Pada hari ke 10, 13, 24 dan 28 penelitian terjadi super ovulasi yang mana diantara itik penelitian perlakuan 2 memproduksi 2 butir telur dalam satu hari. Energi yang dihasilkan sebagai akibat dari sinar laser ternyata menimbulkan stimulasi pada syaraf perifer sehingga menyebabkan penggertakan hipotalamus untuk mempro- duksi Gonadotrophin Releashing Hormon (GnRH). GnRH ini akan merangsang pituitary anterior untuk memproduksi FSH dan LH.

FSH ini akan memicu perkembangan dan pertumbuhan folikel, selanjutnya folikel akan mensintesis estrogen. Bagian dari folikel yang menghasilkan steroid adalah sel theca dan sel granulosa. Pada waktu praovulasi tumbuh, mulai terjadi peningkatan seksresi hormon progesteron oleh lapisan sel theca, peningkatan progesteron ini menyebabkan lapisan granulosa lebih responsif terhadap hormon LH pada saat folikel mendekati ovulasi. Progesteron selanjutnya menggertak penigkatan kadar LH yang menyebabkan ovulasi. Sementara itu hormon estrogen merangsang terjadinya hipertropi dari dinding oviduk dan diferensiasi dari daerah sekretoris. Sisa estrogen akan bekerja sama dengan progesteron untuk menggertak sekresi putih telur dan memobilisasi kalsium dari ujung tulang panjang (epifisa) untuk menigkatkan pengeluaran kalsium dan membentuk cangkang telur (Hafez, 2000).

Penelitian yang sukses juga telah dilakukan oleh Binawati dan Fatmawati (2005), penembakan laserpunktur pada titik ova ayam arab berdampak signifikan pada produksi telur, hasil penelitian 
menunjukkan ada pengaruh yang sangat nyata pada perlakuan lama penembakan laser terhadap produksi telur dan total berat lemak di dalam rongga abdominal ayam Arab. Terlihat pada perlakuan penembakan laser dengan durasi 15, 30 dan 45 detik. Berturut-turut menghasilkan produksi telur yang semakin tinggi, sedangkan pada perlakuan tanpa laser produksi telur kurang tinggi yang diikuti dengan penurunan produksi telur. Penelitian juga dilakukan oleh Idayatih (2014) menggunakan laser Helium Neon terhadap pertambahan berat badan per minggu itik Madura jantan menunjukkan hasil yang tidak berbeda nyata pada pertumbuhan minggu ke-0 hingga minggu ke-3, namun perbedaan nyata dapat dilihat pada pertumbuhan itik minggu ke-4 dan minggu ke-5 yang diberi penembakan laser Helium Neon.

Titik akupunktur yang di tembak laser dengan dosis 0,2 joule dapat mendapat rangsangan yang cukup baik tetapi penembakan laser dengan dosis 0,5 joule memberikan rangsangan aliran elektron pada sel yang lebih optimal sehingga menyeimbangkan kinerjanya dan merangsang organ target melalui meridian. Meridian merupakan sel-sel yang mempunyai sifat kelistrikan yang spesifik (resonansi yang sama), apabila memperoleh rangsangan energi akan disalurkan secara dinamis sepanjang jalur yang dibentuknya dan menuju ke organ target. Organ target akan mendapatkan rangsangan biokimia berupa peningkatan produksi enzim dan hormon serta rangsangan fisiologi berupa peningkatan konsumsi oksigen, peningkatan cardiac output dan peningkatan aktivitas organ (Adikara, 2014). Titik akupunktur yang terdiri dari kumpulan sel-sel spesifik aktif mempunyai model reaksi terhadap energi, terjadi perubahan polarisasi sel dan produksi energi intraseluler dan protein mitokondria (Saputra, 2000).

Penembakan laserpunktur dengan dosis $0,2-0,5$ joule dapat mempengaruhi langsung organ target secara keseluruhan sehingga meningkatkan kualitas reproduksi dari itik Campbell betina secara menyeluruh dan dapat bermanfaat dalam efisiensi betina dan produksi telur serta peningkatan daya tetas telur. Penembakan laserpunktur pada itik Campbell betina perlu dilakukan dalam fase growing dan awal fase layer guna mengoptimalkan fungsi organ reproduksi, setelah masa layer produktif dan stabil penggunaan laserpunktur bisa diberhentikan.

\section{Kesimpulan}

Berdasarkan penelitian dan pembahasan hasil yang telah dilakukan didapatkan kesimpulan bahwa penembakan laserpunktur pada titik reproduksi itik Campbell betina dengan interval penembakan 3 hari dengan dosis 0,2 joule $-0,5$ joule dapat menigkatkan produktivitas telur karena energi listrik menimbulkan rangsangan pada hormon.

\section{Daftar Pustaka}

Adikara, R.T.S. 2014. Teknologi Laserpunktur pada Ternak [Diktat]. Fakultas Kedokteran Hewan. Universitas Airlangga. Surabaya. 5-66.

Adikara, RTS. 2001. Teknologi Laserpunktur Pada Ternak. Pusat Penelitian Bioenergi. LKPM Universitas Airlangga. 7-23.

Atmadjaja. 2003. Beternak Itik Hibrida Unggul. Penebar Swadaya. Bandung. 12-18.

Binawati, D. K dan D. Fatmawati. 2005. Pengaruh Penembakan Laser Terhadap Produksi Telur Dan Berat Lemak Abdominal Ayam Arab, J of Science. 1(1):17 - 21 .

Hafez, E. S. E., and B. Hafez. 2000. Folliculogenesis, Egg Maturation, Ovulation. In Reproduction in Farm Animal. 7th Edition. Lea and Febiger. Philadelphia. Chapter 5. 68.

Hafez, E. S. E. 2000. Reproduction in Farm Animals. 7th Ed. Lea \& Febiger. Philadelphia. 385-393.

Hardjatno, T. 2001. Dasar-dasar Laserpunktur. Seminar Persatuan Akupunkturis Seluruh Indonesia (PAKSI) $9-10$ Juni 2001. Jakarta.

Hardjosworo, P.S dan Rukmiasih. 2000. Meningkatkan Produksi Daging Unggas. Penebar Swadaya, Anggota IKAPI. Jakarta. 15-35.

Herdis. 2005. Optimalisasi Inseminasi Buatan Melalui Aplikasi Teknologi Laserpunktur pada Domba Garut (Ovis aries). Disertasi. Bogor: Sekolah Pascasarjana, Institut Pertanian Bogor. 25-39. 
Idayatih, T. R. 2014. Potensi Teknologi Laserpunktur Helium Neon Terhadap Berat Badan dan Pertambahan Berat Badan Per Minggu Itik Pejantan Madura [Skripsi]. Fakultas Kedokteran Hewan. Universitas Airlangga.

Ismoyowati, T., J.P. Yuwanta., H. Sidado$\log$ dan S. Keman. 2006. Hubungan Antara Karateristik Morofologi Dan
Performans Reproduksi Itik Tegal Sebagai Dasar Seleksi. Fakultas Peternakan Universitas Gadjah Mada, Yogyakarta. 152-156.

Saputra, K. 2000. Akupunktur Dalam Pendekatan Ilmu Kedokteran. Airlangga University Press. Surabaya. 8-38. 